\title{
DOCUMENTING ANCIENT THRESHING FLOORS AS PART OF OUR TANGIBLE/INTANGIBLE CULTURAL HERITAGE FROM ARCHIVE AERIAL PHOTOS: A CASE STUDY IN CYPRUS
}

\author{
E. Fotiadou ${ }^{1}$, E. Stylianidis ${ }^{2}$ \\ ${ }^{1}$ School of Spatial Planning and Development, Faculty of Engineering, Aristotle University, Thessaloniki, 54124, Greece - \\ effotiadou1@gmail.com \\ ${ }^{2}$ School of Spatial Planning and Development, Faculty of Engineering, Aristotle University, Thessaloniki, 54124, Greece - \\ sstyl@auth.gr
}

KEYWORDS: photointerpretation, threshing floors, GIS, archival aerial photographs, tangible and intangible cultural heritage, photogrammetry

\begin{abstract}
:
Threshing floors are common cultural features of the Mediterranean agricultural landscape and have been used from antiquity until some decades ago to thresh grains. Therefore, they constitute an integral part of our tangible and intangible cultural heritage as they are constructions that are linked with complex relationships between crops, technology, folklore, local materials and traditions from our ancestors. However, today, threshing floors are obsolete and destroyed almost everywhere due to modern development and very little attention has been given by archaeologists to these important cultural features. The identification and recording of ancient activity areas such as threshing floors is an important part of archaeological research contributing to the reconstruction of past ways of life and to the preservation of inherited traditions from the past. Access to historical archives of aerial photographs provide a highquality photographic record, offering considerable potential in detecting ancient threshing floors that do not exist anymore because they have been buried in the course of time or destroyed. This study was conducted to deploy a methodology that deals with the identification of ancient threshing floors and their remains in the island of Cyprus through photo interpretation, by utilizing archival aerial imagery in combination with supplement ethnoarchaeological information.
\end{abstract}

\section{INTRODUCTION}

Threshing floors are common features of the Mediterranean agricultural landscape and have been used since the most ancient of times to thresh grains. Archaeological reports show that threshing floors date back to Late Neolithic, Chalcolithic Age, and Bronze Age and they were first used in Turkey, Syria, and the Balkans. Furthermore, according to archaeological evidence, large quantities of grain were exported from Cyprus in antiquity, which implies to the use of threshing floors in Cyprus on those ages (Yerkes, 2011). Since those ancient times and until some decades ago, threshing floors were still widespread used by farmers, throughout most of southern Europe and Southwest Asia. In Cyprus, every agricultural village and town used to have at least one threshing floor until the mid-50s (Whittaker, 2000).

At their most basic level, threshing floors were locations, and more specifically were specially flattened outdoor circular and paved hard surfaces made of earth or stone, where farmers used to perform the agricultural activities of threshing and winnowing of the grain harvest. The result of these activities was the separation of the grain from the straw in order to be freed from the chaff and become edible (Whittaker, 2000; Yerkes, 2011; Waters, 2013). Grain crops all around the Mediterranean were commonly threshed by a wooden threshing board also called threshing sledge, which was mostly driven by animals over grain sheaves strewn on a threshing floor (Whittaker, 2000).

As sites where crops were processed, threshing floors were essential part for survival in rural societies (Waters, 2013). Each threshing floor was usually owned by a single family, and it was located outside the village in a place exposed to the wind (Simpson, 2009; Whittaker, 2000). Threshing was a social occasion and neighbors frequently cooperated, exchanging labor (Waters, 2013; Given, 2014). Taking into consideration that cultural heritage is an expression of the ways, the traditions, the folklore, the values and the practices of living developed by a group of society that are inherited from past ancestors and passed to next generations, it is abundantly clear that threshing floors are an integral part of our tangible and intangible cultural heritage as they reflect complex relationships between crops, technology, local materials and traditions from our ancestors (ICOMOS, 2002; Sullivan, 2016). They relate to subsistence practices in agricultural societies and are of significant architectural, land-planning, social, folklore and generally of historic importance (Waters. 2013; Palmer \& Thérond, 2008).

Notwithstanding their cultural importance, due to the fact that threshing floors separated from habitation and associated with few artefacts, they have received little attention from archaeologists, beyond brief descriptions in reports of regional documents (Whittaker, 2000). Today, threshing floors are obsolete almost everywhere, and the traditional practices are becoming extinct and replaced by modern farm machinery. Human interference and natural mechanisms such as modern development, road building, modern agricultural activities and water erosion are steadily taking place over threshing floors and destroy the archaeological remains (Darvil and Wainwright, 1994). Unfortunately, today most of threshing floors are buried or destroyed to build new houses. 
The identification and recording of ancient activity areas such as threshing floors is an important part of archaeological research contributing to the reconstruction of past ways of life and to the preservation of inherited traditions from the past. Although there are many small artifacts and tools related to traditional threshing practices, threshing floors, due to their special circular shape, construction material and size, produce the most distinctive archaeological traces that can be identified (Whittaker, 2000). Their spatial identification in combination with ethnoarchaeological information about threshing floors, allow the interpretation of archaeological remains. It is very crucial to collect the ethnoarchaeological information in the immediate future, before the few remaining old people that remember the traditional agriculture are gone.

A way to analyze and study ancient landscapes and constructions as they were before any alterations happened to them, is by employing archival aerial photographs. Access to historical archives of vertical photographs acquired for other purposes such as military, cadastre, etc., provide a high-quality photographic record, offering considerable potential for archaeological and historical landscape research (Hanson \& Oltean, 2013). This photographic material is essential in detecting ancient constructions that do not exist anymore because they have been buried in the course of time or destroyed. Nonetheless, it is important to emphasize that for the successful transformation of aerial data into useful archaeological information, the interpretation process is the most critical step in identifying ancient remains (Raczkowski, 2014).

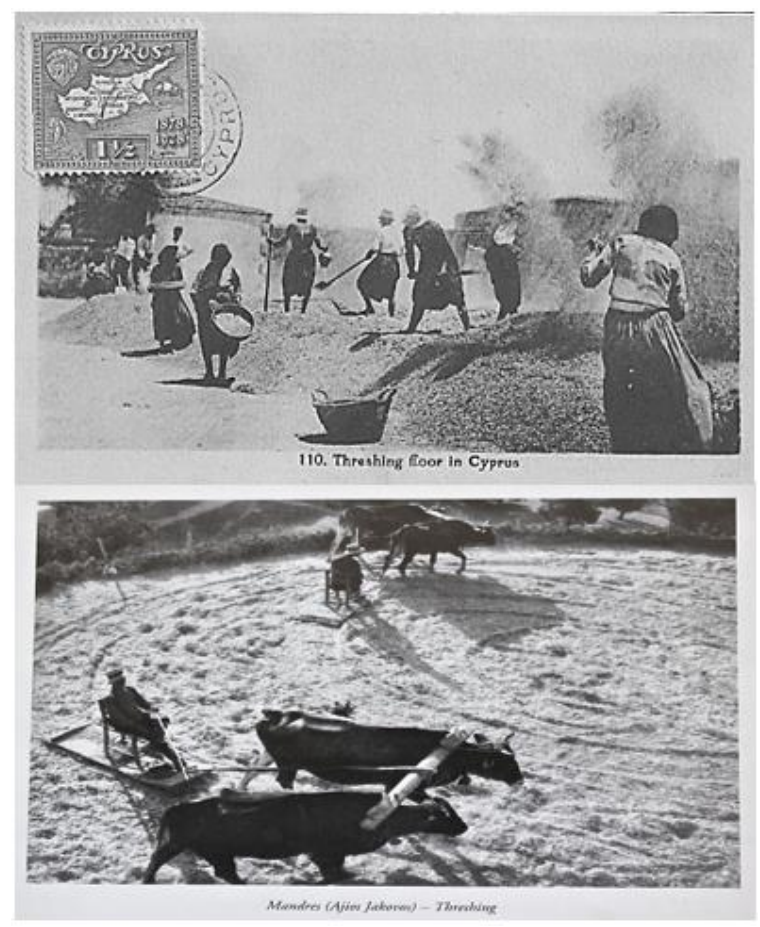

Figure 1. Old Postal Cards depicting scenes during threshing and winnowing process in Cyprus during $30 \mathrm{~s}$.

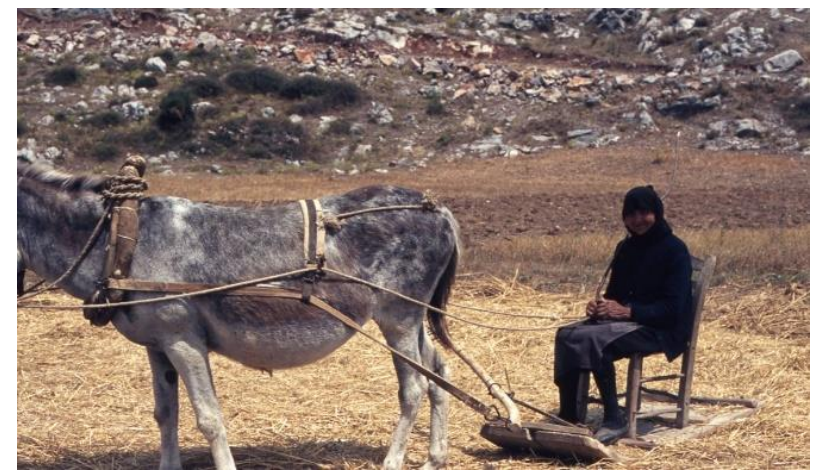

Figure 2. Recent Traditional Threshing scene in Cyprus during 60s. (C) Cyprus Exploration unlimited 2021

\section{DATA AND METHODOLOGY}

Given that aerial photos can capture all visible features on the Earth's surface from an overhead perspective, historical imagery can significantly contribute to recover information about historic landscapes that have been lost to modern development. Historic aerial images constitute an invaluable source of aid to the study of archaeological and culture heritage sites (Patias et al., 2011).

This study deals with the identification of ancient threshing floors and their remains in the island of Cyprus by employing both archival and recent aerial photographs. More specifically, historical images of Cyprus acquired in 1963 from the Cyprus Department of Lands and Surveys, were used to turn back time to reconstruct the historic landscape, retrace ancient agriculture heritage and reveal ancient threshing floors that are no longer visible due to modern urban development and farming. The documentation was based on visual aerial photo interpretation cross-checked with testimonies of the few old remaining local villagers.

Archival aerial photographs formed the primary datasets for this study. The aerial photographs which were used pertain to the year of 1963 with a spatial resolution of approximately $1 \mathrm{~m}$ and an area coverage of about $3 \mathrm{~km} \times 3 \mathrm{~km}$. These photographs were available from the Department of Lands and Surveys in Cyprus, which were acquired during airborne campaigns for mapping purposes. Given the long period of time that has passed between now and 1963, these photographs constitute a vital source for archaeological investigation since they have been produced before modern development started to alter landscapes in Cyprus, and therefore provide an unadulterated view of the landscape as it was many decades ago.

However, these archival photographs are single-band monochromatic and are lacking in terms of spectral and spatial resolution. The monochromatic nature of archival aerial photographs makes their interpretation more difficult and by taking into consideration their scale, many features on land appear blurry and hazy. For this reason, enhancements were essential to make it easier for visual interpretation and identification of threshing floors.

To exploit aerophotographs in an efficient way, it was essential to pre-process imagery in order to be on the right format to 
extract accurate and measured information about threshing floors. The pre-processing step included the georeferencing of photography and the process of image enhancement.

The first step in aerial photointerpretation is to transform all the data into the same reference frame. This procedure, called "georeferencing", is a strict mathematical transformation, which transforms image's internal coordinates into ground system geographical coordinates. In this way, all digital image files were associated with real location coordinates in physical space in order to extract measurable information from them. The coordinate reference system that was chosen was the official projection that is used for the onshore area of Cyprus, the Cyprus Local Transverse Mercator (LTM). This projection uses as a datum the Cyprus Geodetic Reference System 1993 and the ellipsoid WGS 84. For the projective transformation control points were collected from the contemporary orthorectified aerial mosaics that are freely available in the official site of Cyprus Department of Lands and Surveys. As control points were selected discrete areas such as permanent constructions that existed both in 1963 and still appear on current photomosaics. The spatial resolution of the final orthorectified aerial photographs is $0.7 \mathrm{~m}$.

Given the need to improve and enhance the optical quality of such data to allow a more credible interpretation, high-pass filters and adjustments of contrast, lightness and clarity were applied on photography (figure 3). More specifically, this was achieved by applying a raster histogram equalization on imagery, which adjusted image intensities in order to enhance contrast in images while preserving detail. This technique spreads out the most frequent pixel intensity values which allows image areas that have lower contrast to gain a higher contrast.

Once imagery was ready to be used, it was vital to define the parameters that determine if a feature on a photo is a threshing floor or something else. In order to interpret and identify threshing floors accurately as they appear on images, specific parameters were considered such as shape, size, tone, shadow/height and association (clustering). These parameters were collected based on the literature in combination with old photographs, old colonial cadastral maps with marked threshing floors and testimonies of the few old remaining locals in the village. A feature was considered as a threshing floor if only it fulfilled all, or most of the following requirements:

- Shape: Threshing floors must be flattened circular formations on earth

- $\quad$ Size: Threshing floors in Cyprus have usual diameter between 8 and 11 meters, sometimes bigger.

- Shadow: In some cases, threshing floors may be paved with a low stone wall. Since the length of shadow of an object is in direct proportion to the height of the object, if a threshing floor is paved, shadows of short length will appear on the one side of the feature.

- Texture: The texture of the surface material may be a smooth floor of earth or stone.

- Vicinity to other features. In most cases, there are more than one threshing floors in the same area, which creates clusters of threshing floors.

- $\quad$ Adjacent to villages
- Threshing floors must be located close to the village, but outside the village perimeter to avoid long distances for transport. Their distance is never more than $200 \mathrm{~m}$ away from the village.

- The area extent of a threshing floor most probably is still enclosed within the existing parcel boundaries. To take this parameter into consideration, the location of identified threshing floors was overlapped with a shapefile that contains the official cadastre parcel boundaries.

Most often, threshing floors are located in hilled areas that are exposed to the wind.
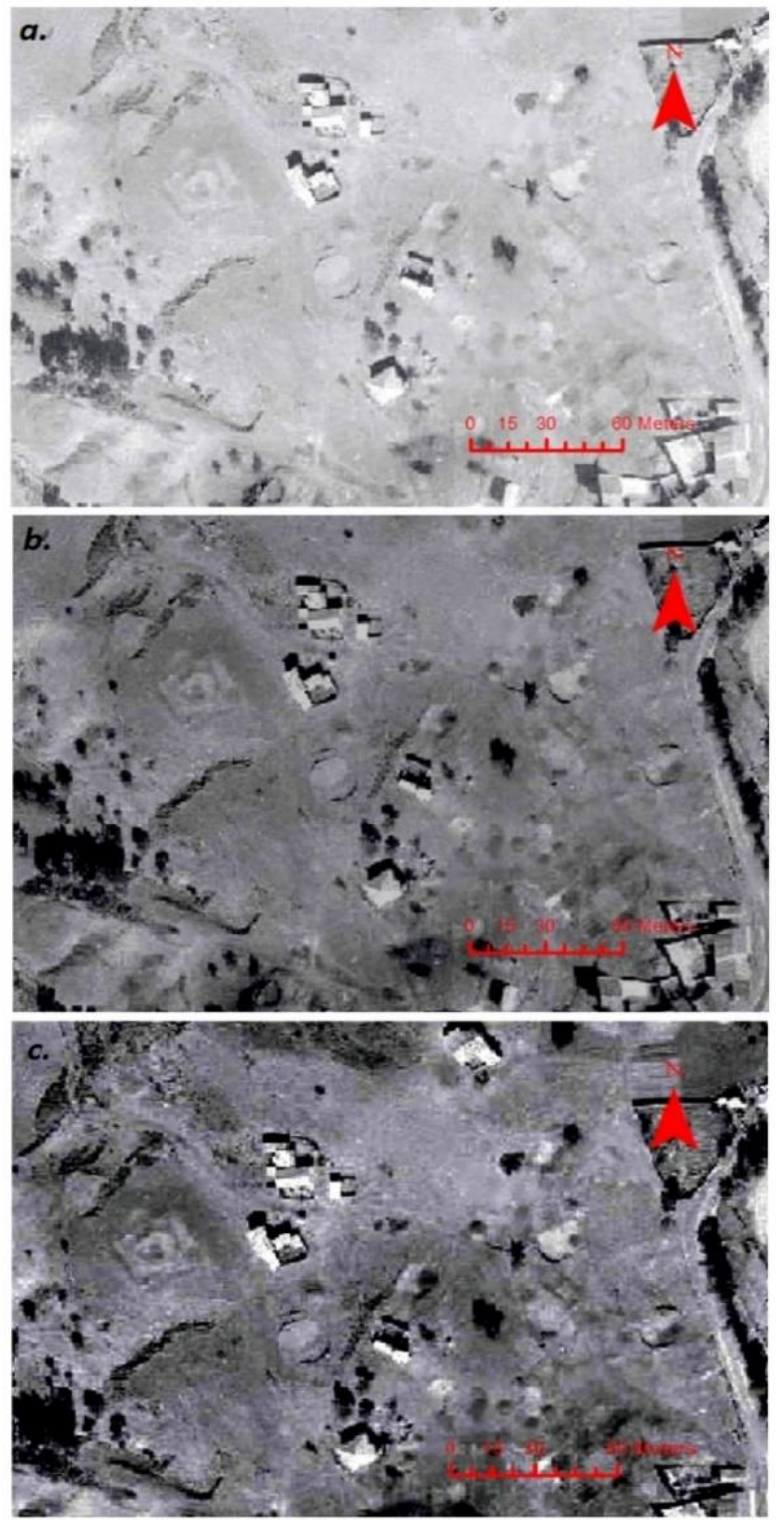

Figure 3. Part from an aerial photograph of 1963 used in this study; a. original photograph - no enhancement applied, b. contrast adjustments applied, c. histogram equalization applied. 


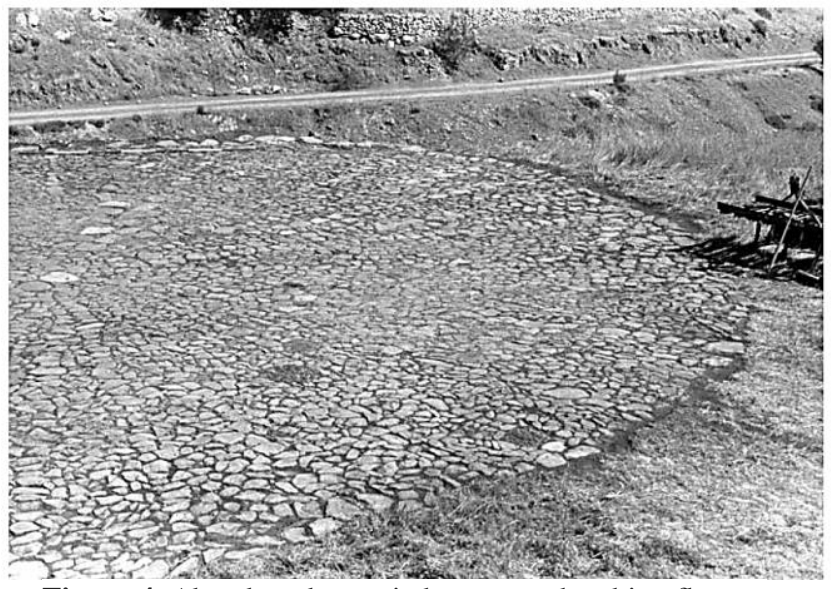

Figure 4. Abandoned twentieth-century threshing floor at Mitsero village, Cyprus (Given, 2014)

The spatial identification of threshing floors was executed in ArcGIS. Every identified threshing floor was vectorized and its geometric, geographic and descriptive information was recorded in the database.

The study had 3 different objectives:

1. Firstly, a map was created documenting all threshing floors, houses and roads in Klirou Village as they were in 1963. In this map, all threshing floors were documented based on photo-interpretation and then validated by local old people testimonies.

2. In the second part, areas of different villages in different areas all over the country of Cyprus were randomly chosen to examine if there are differences on the construction materials, dimensions and placement of threshing floors throughout the Country.

3. Last but not least, in the third part, threshing floors that were interpreted in imagery of 1963 were compared with the recent imagery of 2014 to assess if there still are any visible threshing floor remains, and if yes, in what condition are they.

\section{RESULTS}

\subsection{Photo interpretation and documentation of threshing floors in a pilot village area in Cyprus}

Figure 5 depicts a map with the threshing floors, the buildings and the roads existed in the village of Klirou in Cyprus in 1963, as they have been interpreted and documented on the aerial photograph.

All threshing floors depicted on the map were interpreted and then cross checked with the spoken testimonies of inhabitants. Interpretation results show that threshing floors that documented on the map of Klirou village meet and validate the definition that was formed based on old inhabitants' interviews and the literature. First of all, threshing floors indeed are situated around the edge of the village houses, rather than in the open countryside near people's fields. As for their spatial distribution, it is clear that all threshing floors are clustered together in two group areas on the more exposed edges of the village, to get the best wind for winnowing and as well as because of the desirability of cooperative labor and socialization. Based on the map, most threshing floors were very close to the houses, in an average distance of $100 \mathrm{~m}$ to $200 \mathrm{~m}$ away from the village.

According to old villagers, each threshing floor was owned by specific families and the total number of threshing floors show the scale of each village economy. The size and construction material of threshing floors showed the social status of each family. Richer families had bigger threshing floors made of stones and often decorated with patterns, whereas poorer families threshed their grains in smaller areas on earth ground. In addition, the spatial distribution of threshing floors reflects the richness of each family. Interviewed old residents in Klirou village said that threshing floors that were located in the northwest cluster of the village were owned mostly by the richest families of the village. These threshing floors were outbalanced those that were in the southeast cluster because that area was more hilled in terms of wind, and had more fertile soils in terms of yield production.

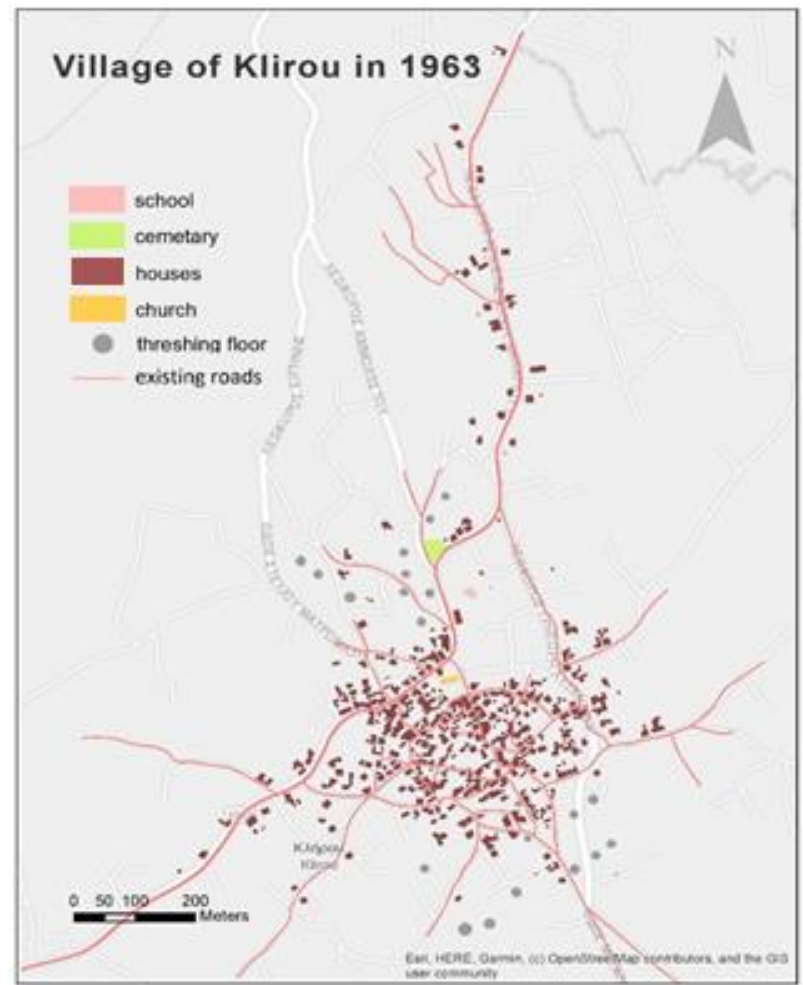

Figure 5. Map of the village of Klirou produced in a GIS environment through photo interpretation of aerial imagery taken in 1963.

\subsection{Identifying survived threshing floors by comparing archival and contemporary imagery}

In all villages that were examined, threshing floors appear in photos as clusters of assembled bounded circular formations on earth with a diameter of about 12-25 meters, looking like Moon craters located on specific elevated areas near villages.

It is very interesting that by comparing archival aerial photography with contemporary aerial photography, some threshing floors that were interpreted in the historic imagery they found to still be present in the modern landscape. In most cases, threshing floors that survived are located in traditional villages that were abandoned due to urbanization or due to political events. Characteristic example is the Zacharia village 
in Paphos (figure 8), which was abandoned in 1974 due to the Turkish occupation of the half island and since then threshing floors remain intact until now (figure 6). Unfortunately, expect from some instances, in most of the cases ancient threshing loors that were detected in 1963 imagery, in 2014 imagery they were replaced by modern constructions and swimming pools (figure 6 and 9) or converted into cultivated land (figure 7).A single threshing floor in Politico village in Nicosia that belongs to a monastery, has a very large size (approx. 40m in diameter) rather than a family floor (typically $12-15 \mathrm{~m}$ ). Today, this threshing floor does not exist anymore since a church was constructed over it (figure 9).

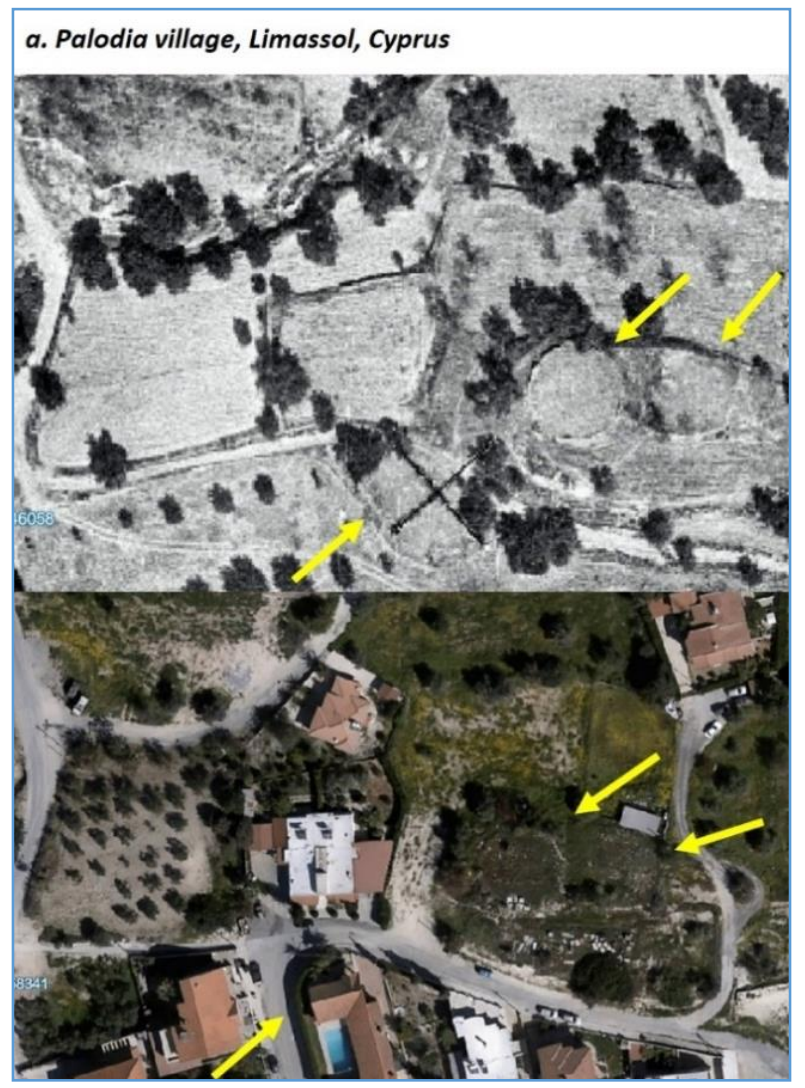

Figure 6. Threshing floors detected in Palodia village in 1963. Today some threshing floors still appear on photographs whereas some others have been replaced by modern building constructions and swimming pools.

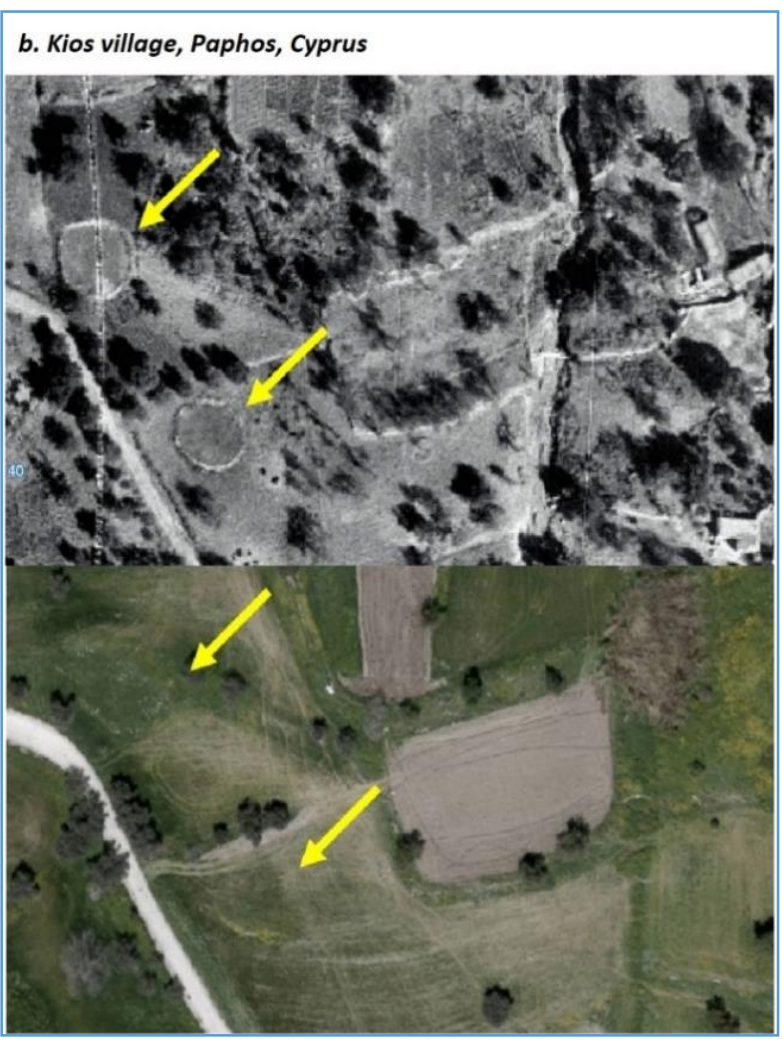

Figure 7. Threshing floors detected in Kios village in 1963. Today these threshing floors are destroyed.

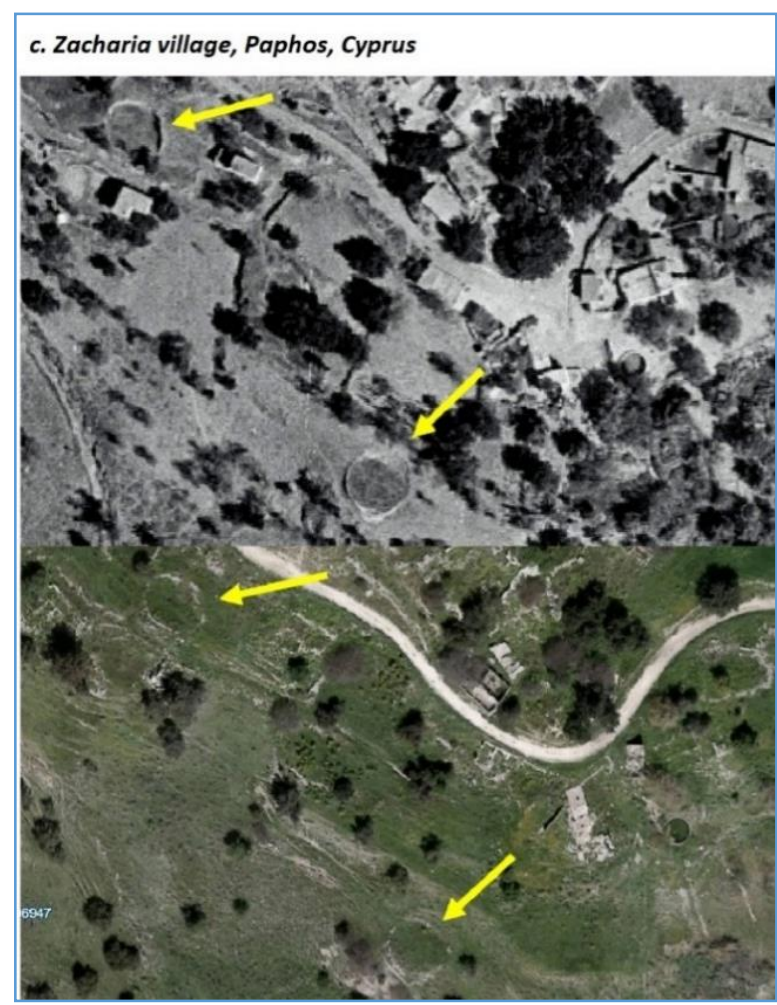

Figure 8. Threshing floors detected in Zacharia vilalge in 1963. Today threshing floors still remain alive since the village was abandoned after Turkish occupation on the island. 


\section{d. Politiko village, Monastery of Saint Heracleidios}

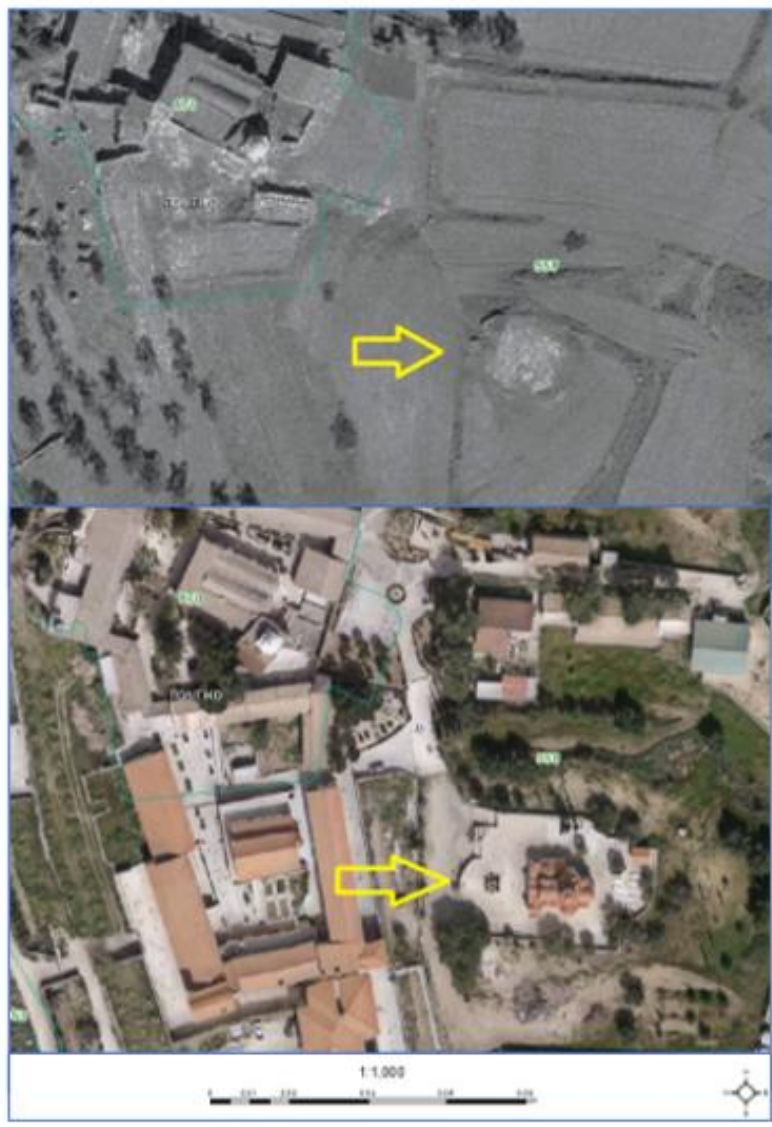

Figure 9. Threshing floor detected in 1963 photography in Politiko village. Today there is a church on that area.

\subsection{Comparing characteristics of threshing floors around Cyprus}

After examining aerophotographs over a plenty of different villages in each municipality of Cyprus, it was clear that there is no village in 1963 that has not had at least one threshing floor. By looking at figure 10, it is also evident that in all villages threshing floors are very close to villages. While fields are at some distance, all threshing floors are near the villages for ease of transporting the chaff and threshed grain to storage.

While in some villages there are few threshing floors, in others there are many clusters of multiple threshing floors. The presence of large or multiple threshing floors indicates wealth, high fertile soils and productivity and cooperative labor (Yerkes, 2011, Given, 2014). Furthermore, by considering the construction material of threshing floors there are many differences along different areas of Cyprus. For example, in Paphos and Limassol, where soils mainly consist of limestones, threshing floors seem to be shown whiter on photos. In contrast to that, in Ammochostos, Kerynia and Nicosia where soils are darker, threshing floors are darker because they were made of river cobblestones and field stones. It is also evident that shadows around some threshing floors indicate that in some villages threshing floors are enclosed by low walls.

During the identification process of threshing floors, in big villages near cities that are famous for their cereal productivity, it was realized that no threshing floors detected in 1963. This is a logical outcome, since the first power-driven threshing machine came to Cyprus in 50s, and thus, villages with high productivity used these machines very early.
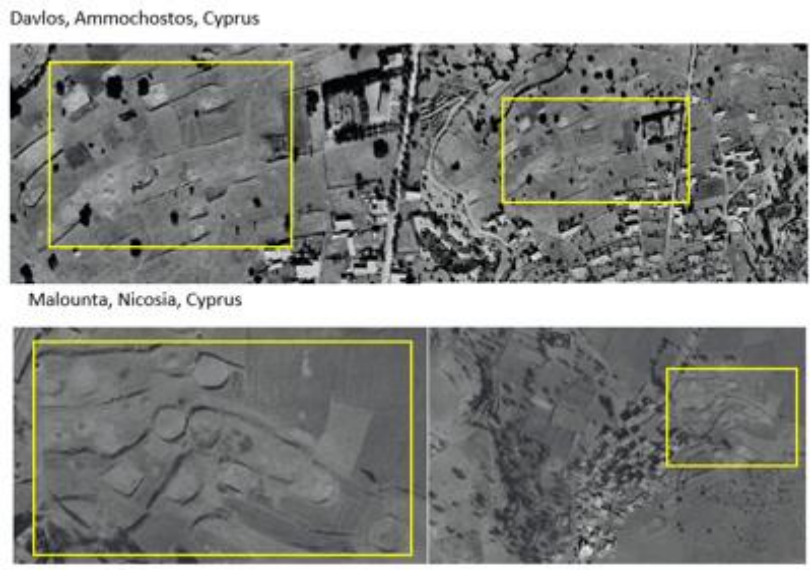

Kinousa, Paphos, Cyprus

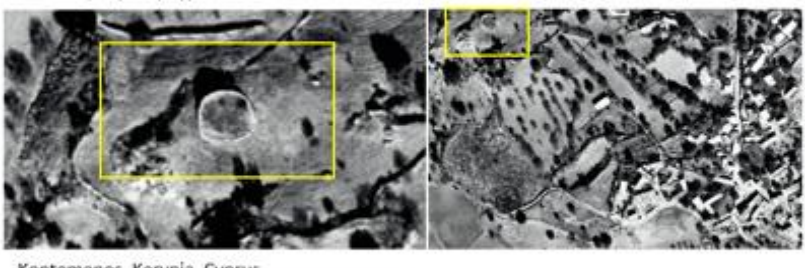

Kontemenos, Kerynia, Cyprus
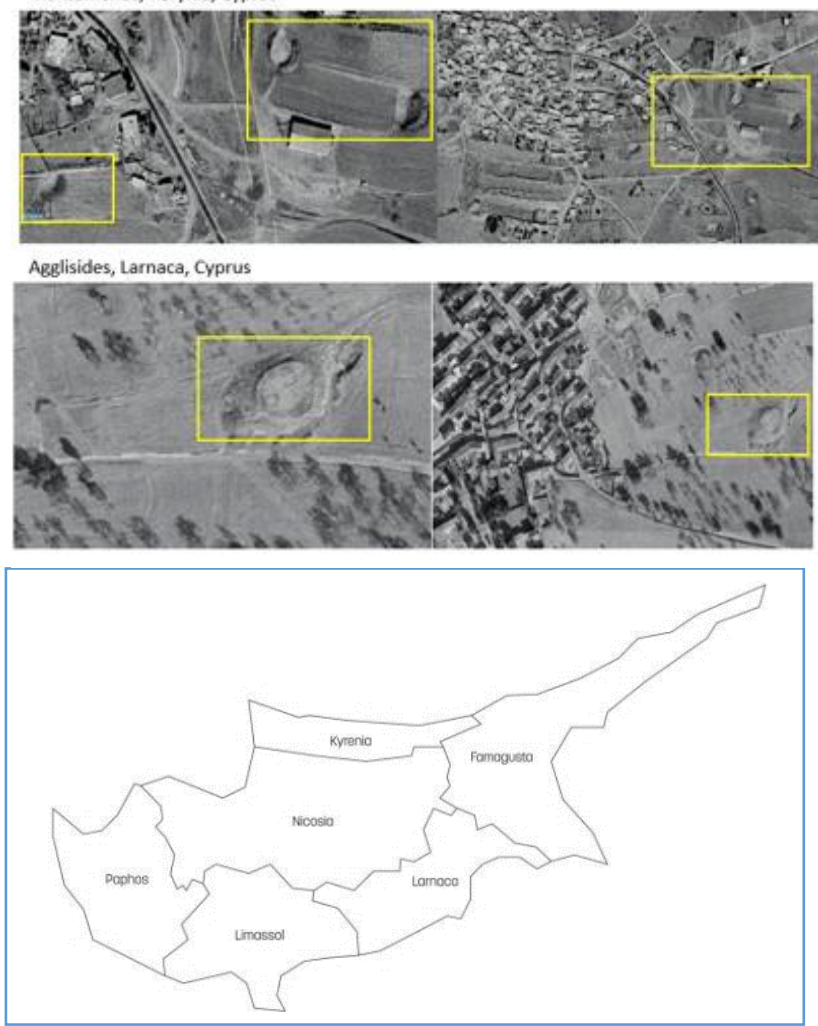

Figure 10. Detected threshing floors in different places along the 6 different Cyprus districts which are shown on the overview map.

\section{DISCUSSION}

Archival aerial photographs are a precious source to identify heritage objects, and to monitor change and damage to historic objects of the past. 
In the case of Cyprus, threshing floors have been permanently abandoned and died off since $50 \mathrm{~s}-60 \mathrm{~s}$, when the first powerdriven machine arrived in the island. Unfortunately, since then, cultural monuments such as ancient threshing floors are not protected by any proper law, and as a consequence, most of them were destroyed and converted into plots where new houses were built. Today, one can find few remaining neglected threshing floors in some areas of traditional villages of Cyprus.

In this study archival aerial photography was used to identify ancient threshing floors in the area of Cyprus. By utilizing archives of aerial photographs, threshing floors were easily detected in the landscape, even when they no longer survive.

However, although documenting threshing floors through the use of archival areal imagery seems to be very fruitful in ethnographical studies, there are also some major limitations. First limitation of this method is the difficulty to date threshing floors. They may be detected, but it is impossible to be dated, since there is no evidence or any testimony of elder people about the date of their construction. Threshing floors range from ancient to contemporary and can be found almost in every village. All old people that were interviewed for this study, as well as informant from other studies that were used in the literature review, none knew when threshing floors had been built, but all agreed that they were built by individual agricultural families with the help of friends. An important source of information about when threshing floors were constructed may be given indirectly by old cadastral maps at scale of 1:5000 and village maps at 1:1250, where threshing floors were surveyed by English colonial surveyors for taxing purposes. These were drawn up in the 1881 census, and posterior revised maps of 1980 may still have even abandoned threshing floors marked. For example, based on the map created by Given, 2014 (figure 11), Klirou village had about 4 threshing floors in 1880, whereas in 1963 up to 19 threshing floors were detected. This means that most of the threshing floors identified in this study they were constructed after 1880s.

The scale of archival aerophotography was another factor that made interpretation harder. Due to the small-scale of 1963 photography, bigger areas were covered with less detail, which made it difficult to identify features in the size of threshing floors. Important auxiliary details that are needed for accurate detection of threshing floors such as walls, flagstones and surface texture were lost in the pixelated imagery. However, the spatial resolution of 1963 photography was proved enough capable and efficient in documenting threshing floors.

Furthermore, during the process of detecting threshing floors, it was realized that it is of great significance to correlate predictions made from air photos with other supplementary sources of information such as published literature, maps, old photographs, postal cards, and interviews from locals. In the top of these, the most important source are the field data which permit validation of findings. In the specific study, in the case of some villages which were easy to access, detected threshing floors were field checked with photos in hand. In this way, abandoned threshing floors that may not be visible in contemporary aerophotographs due to vegetation cover and ground embankments, but still exist, can be discovered. This process is very crucial, while it is the start point for reconstructing and preserving the any remaining threshing floors that are still survive.

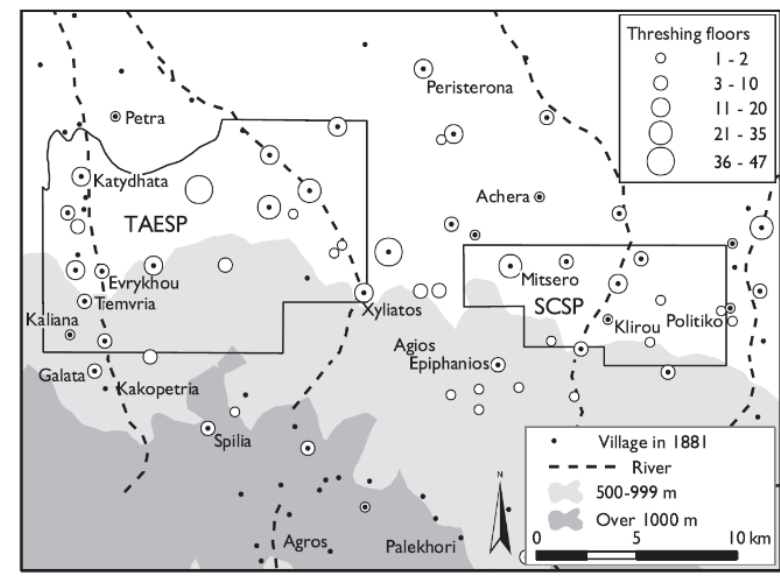

Figure 11. Northern Troodos mountains, Cyprus; villages recorded in the 1881 Census, and distribution of threshing floors (Given M., 2014)

Another constraint that should be considered are the uncertainties of human eye and perception. Aerophotographs are the window through which interpreters project their background to determine what is in the view. It is within interpreter's knowledge, experience, imagination and ability to follow logic and reason, to identify, analyze, evaluate, and interpret what is in the view. Photo interpreter visualizes how the landscape looks from the camera vantage point in the air, and if interpretation is made wisely, then accurate findings and predictions will result. However, interpreter still becomes one of the limiting factors to successful photo analysis. For example, in this study, in some cases, based on the parameters that define a threshing floor, features that are not threshing floors in reality, were detected. These constitute basically circular water tanks made of stone which are located near villages, whom formation, texture and dimensions were very similar with threshing floors. However, in the areas where the interpreter's knowledge and training were coupled with field sampling and local testimonies, erroneous detections were excluded, and really accurate and reliable findings were brought.

Last but not least, due to the fact that photo interpretation is based on a manual process, only some random samples of area extends all over Cyprus were studied. Time was a limiting factor because of the large number of prints necessary to be studied thoroughly in detail. However, since threshing floors are simple in their form and represent a common occurrence, they were identified and evaluated easily. On the whole, a systematic procedure of many different areas takes time. Notes were taken, questionable areas were marked, conferences with others were held, visiting in the field were required - all of which requires time.

\section{CONCLUSION}

Although threshing floors were used since ancient times, they have rarely been studied, even though they reveal traditional agricultural practices and ways of past agrarian lives. It is fact that, although threshing floors immense cultural heritage worth, this rural intangible and vernacular heritage is threatened on several fronts. Unfortunately, many of them have been destroyed and lost due to modern development and intense agriculture, and any remaining threshing floors are abandoned and under of great risk. It is fact that has been paid 
extraordinarily little scholarly attention to their preservation by now.

This study was conducted to deploy a methodology to document threshing floors by utilizing archival aerial imagery and ethnoarchaeological information. This methodology underlines the potential of archival aerial photography and GIS for the investigation of lost ancient threshing floors. The potential of using archival aerial photography is very high, since it enables to turn back time to reconstruct the historic landscape, retrace ancient agriculture heritage and reveal ancient threshing floors that are no longer visible due to modern urban development and farming. In a broader look, beyond threshing floors, similar methodology can be adopted to document other ancient vanished cultural features of the rural landscape such as water mills and windmills. The importance of introducing this kind of aerial geographical investigation methods to archaeological research, especially in cases where today archaeological evidence is not available, such as the case study presented here, becomes clearly deduced.

It is important that since threshing floors are part of our intangible heritage, their spatial identification and interpretation of their remains can be achieved only in combination with ethnoarchaeological information about threshing floors. For this reason, it is very crucial to study and document threshing floors in the immediate future, before the few remaining old people that remember the traditional agriculture are gone. As modern technologies replace traditional practices, the old agriculture fades away. Only some years remain to record the memories of those who used it and document any remaining ancient features that were used in these practices. When any left old people are gone, only some scarce survived threshing floors and the writings of archaeologists will remain to remember and interpret an agricultural tradition that is many centuries old. If this intangible cultural heritage is not captured, one day this knowledge will be vanished without keeping a footprint for next generations. On the whole, more studies related to the documentation of threshing floors must be conducted, which will raise awareness of the importance of preserving threshing floors and force governments to establish proper national and international laws related to their protection.

\section{REFERENCES}

Darvill, T.C., Wainwright, G., 1994. The Monuments at Risk Survey: an Introduction. Antiquity 68: 820-24.

Given, M., 2004. The Archaeology of the Colonized. $10.4324 / 9780203644188$

Hanson, W. S., Oltean, I. A., 2013. Archaeology from historical aerial and satellite archives. New York, NY: Springer

Lysandrou, V., Agapiou, A., 2020. The Role of Archival Aerial Photography in Shaping Our Understanding of the Funerary Landscape of Hellenistic and Roman Cyprus. Open Archaeology, 6(1), 417-433. https://doi.org/10.1515/opar-20200117

Palmer R., Thérond D., 2008. The rural vernacular habitat, a heritage in our landscape. Futuropa - For a new vision of landscape and territory. Council of Europe Magazine - No $1 /$ 2008 - English

Patias P., Kaimaris D., Stylianidis, E., 2011. Change Detection in Historical City Centers Using Multi-Source Data: The Case of Historical Center of Nicosia-Cyprus.
Rączkowski, W. 2014. Aerial Archaeology. In C. Smith (Ed.), Encyclopaedia of Global Archaeology. New York: Springer. https://doi. org/10.1007/978-1-4419-0465-2_150

Sevara, C., Verhoeven, G., Doneus, M., 2018. Surfaces from the Visual Past: Recovering High-Resolution Terrain Data from Historic Aerial Imagery for Multitemporal Landscape Analysis. J Archaeol Method Theory 25, 611-642 https://doi.org/10.1007/s10816-017-9348-9

Shahack-Gross, R., Gafri, M., Finkelstein, I., 2009. Identifying Threshing Floors in the Archaeological Record: A Test Case at Iron Age Tel Megiddo, Israel. Journal of Field Archaeology, 34(2), 171-184. 10.1179/009346909791070943.

Simpson J., 2009. Oxford English Dictionary Second Edition (v. 4.0). Oxford University Press.

Sullivan A.M., 2016. Cultural Heritage \& New Media: A Future for the Past, 15 J. MARSHALL REV. INTELL. PROP. L. 604 https://repository.jmls.edu/cgi/viewcontent.cgi?article=1392\&c ontext=ripl

Tartara P., 2008. Historical and modern aerial photography for cultural heritage and environmental knowledge, Proc. SPIE 7110, Remote Sensing for Environmental Monitoring, GIS Applications, and Geology VIII, 711008.

Waters J. L., 2013. Threshing floors as scarced spaces in the Hebrew Bible, Baltimore, Maryland

Whittaker, J., 2000. Alonia and Dhoukanes: The Ethnoarchaeology of Threshing in Cyprus. Near Eastern Archaeology, 63(2), 62-69. doi:10.2307/3210743

Yerkes, R. W., 2011. Crossroads and Boundaries: The Archaeology of Past and Present in the Malloura Valley, Cyprus (pp.321-339), Chapter 26. Viewing the Past through the Present: Ethnoarchaeological Studies of Population and Ancient Agriculture., Annual of the American Schools of Oriental Research, Vol. 65, American Schools of Oriental Research (ASOR), Boston

Zapłata, R., Różycki, S., 2015. Historic aerial photographs in the analysis of cultural landscape - case studies from Poland. 